\title{
Management Accounting and Costs Controlling in Oil Producing Companies: Historical Perspectives
}

\author{
Sokolov A.Y.a \\ Giniatullin Y.M. ${ }^{b}$ \\ ${ }^{a b}$ Kazan Federal University, Institute of Management, Economics and Finance, Kazan, 420008, Russia
}

\section{Doi:10.5901/mjss.2015.v6n1s3p430}

\section{Abstract}

The article is dedicated to retrospective study of the first development stages of the management accounting system and costs controlling in oil producing companies. The paper proposes costs classification, management reports types, on the basis of which the decisions in oil business are made. We have considered enterprise peculiarities influencing the development of management accounting model, costs and results controlling in oil producing companies. Depreciation methods used in the middle of the past century in the oil producing companies of the USA are considered.

Keywords: costs, management accounting, conception, analysis, controlling, oil

\section{Introduction}

In the process of development of management accounting model, costs and results controlling in oil producing companies the following peculiarities of financial data formation in the industry enterprises should be determined:

1. Territorial remoteness and specificity of management accounting and controlling objects (oilfields, boreholes, their system dependent developments). It promotes the organization of costs and results management accounting system in the context of their place of origin.

2. The absence of the incomplete production influences the calculation methods of actual and target costs for oil and gas production.

3. Oil producing process is continuous as opposed to the process of outputs production in processing industry. At the same time, life cycle of oil fields and boreholes functioning are estimated. The change of operational life cycle of boreholes performance causes the change in the volume of oil extraction and the value of extracted products cost accordingly. At the final stages the volume of extraction is reducing, the cost is increasing.

4. Identifying of two interrelated processes: underground and aboveground specifies the recording of costs for equipment repair.

5. Availability of the principal (oil) and associated (gas) products requires the application of the respective methods of cost accounting.

6. Extensive resources are used for maintenance of auxiliary units (boreholes underground and aboveground maintenance shop, transportation department, drilling operations shop, complete equipment procurement shop, power supply shop, etc). Return services of auxiliary units promote implementation of rearrangement methods of both target and actual costs, which influences the results of operations in terms of oil lands or oil production workshops.

7. Significant capital intensity of works. This results in increasing influence on depreciation - the costs element of oil production profitability.

8. Preliminary oil fields geological exploration works (costs of the first stage of boreholes life cycle) is embodied in life cycle costs calculation (LCC).

9. Negligible raw products costs (exclusive use of base materials in the form of chemical agents etc.)

Both German controlling and Anglo-Saxon management accounting system influence the Russian accounting system. Consequently, a point of view stating that the management accounting as a mechanism of costs transformation to the results presents component element of controlling. As a result, management accounting in Russia is comparable with three key elements of controlling, jointly used in the USA, Germany and France: budgeting, internal audit and actual costs and results accounting (fig.1). Depending on the country, controlling includes elements of strategic planning, internal audit, and insurance. 


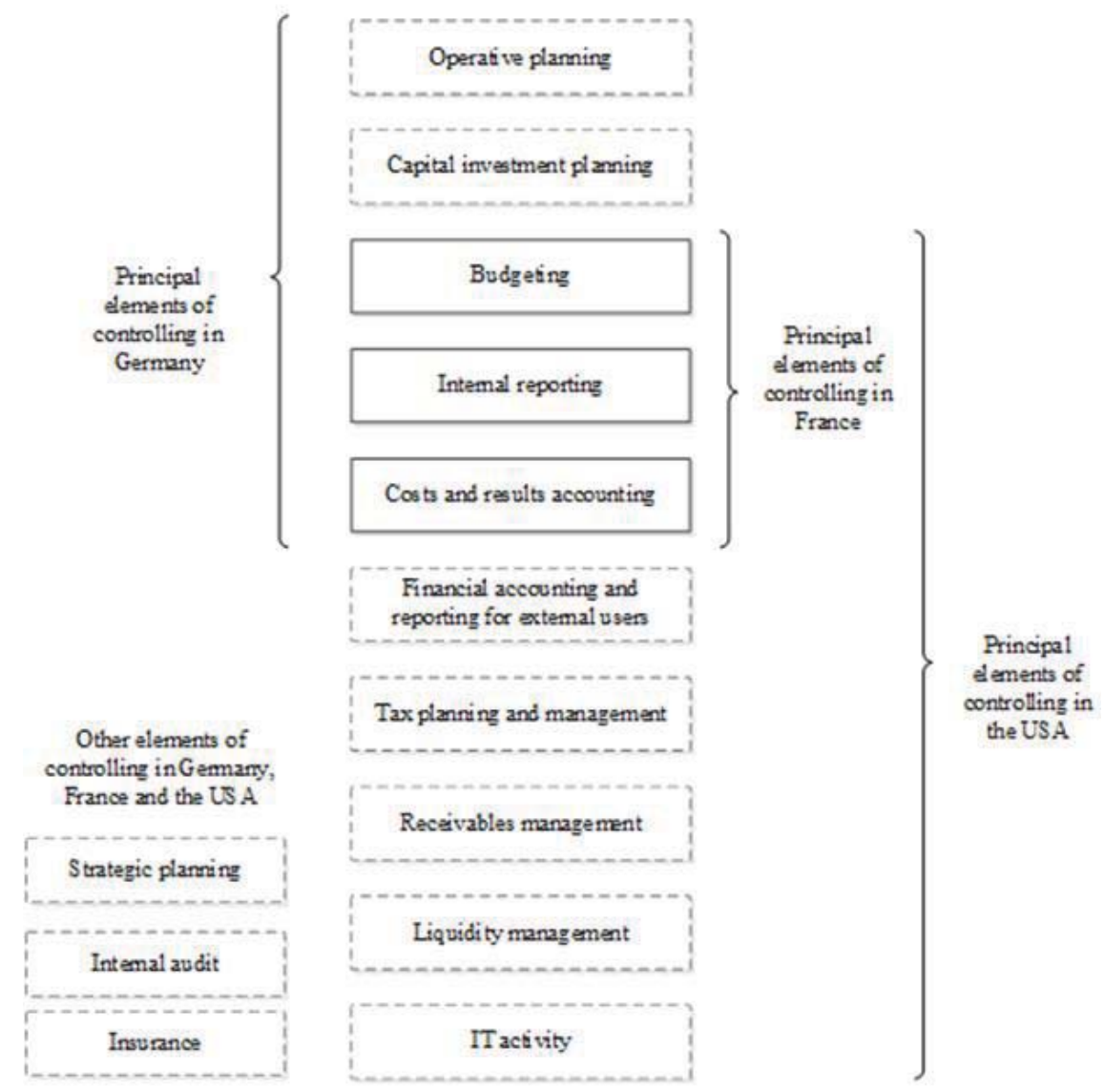

Fig. 1. Elements of controlling

Thus in German controlling the focus is shifted toward data formation for company strategic management, while management accounting in the USA - presents mainly a system for enterprise operative management. Management accounting occurs in all oil producing company's management subsystems (fig.2). Each subsystem has management subject, for example, costs. Herewith each subsystem is autonomous. Horizontal links between the functions allow to form data for the purposes of management.

\section{Method}

The goal of our research is a study of dynamics of costs accounting system development in oil producing companies. The works of Zhou, Q. and Wang, L.[1], Holmes, P. [2]. Bryant, L. [3], Tatikonda, L. and Tatikonda, R. [4], Collins, D. and Dent, W. [5], Bouachera, T., Kishk, M. and Power, L. [6], Kulikova, L.I. [10] are devoted to the issues of costs accounting in oil producing companies.

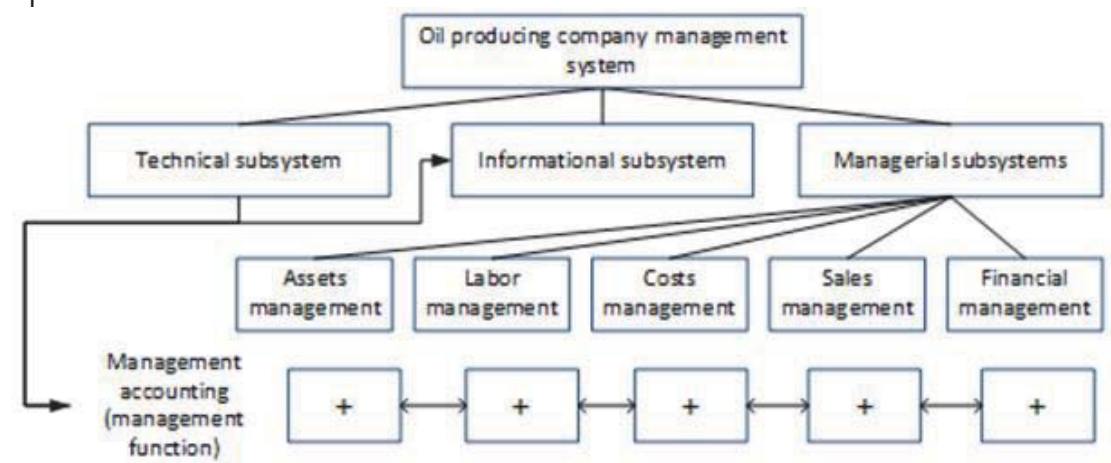

Fig. 2. Management accounting - integrated function of oil producing companies management system 
System approach to creation of costs management accounting was used in oil producing companies of the USA. The works of Smith, C. and Brock, H. [9], Irving, R.,[8] Haynes, L.[11], Finnell, J. [12] were dedicated to the issues of costs accounting. In the beginning of the past century oil companies carried out analysis of productive and operating costs implying the preparation of a special form report with separating and monthly reporting of oil producing direct and indirect production costs. Direct costs included production costs on oil injection, boreholes cleaning and repair. Indirect ones included depreciation of land recourses designated for boreholes construction and depreciation of the boreholes as well. Apart from production costs there were defined operating costs: costs for maintenance of buildings, facilities, fire guard, office equipment and furniture, water supply system etc. In the process of the cost calculation for one barrel the indices of unit direct production, indirect production and operating costs are calculated separately. In 1930-40s these indices were already considered essential in the system of management accounting and controlling in oil producing company. Main designation principles of costs to direct or indirect ones were defined at that period. So the costs became direct in case they correspond to the following criteria: direct connection with production activity; production activity serves as basis of business (oil producing and realization); availability of personnel control, responsible for production activity. Availability of connection with production activity, herewith the lack of control on the part of personnel and some disintegration of activity indicated that the resources expressed in monetary terms and expendable for this activity were included to the indirect costs structure. Direct and indirect costs comprised the group of operating costs. In such a case a register of direct and indirect operating costs was kept. Considering that oil lands themselves served as key objects of management accounting and controlling, labor costs for oil regions (areas) directors were subject to distribution among them. Insurance costs were also considered as indirect operating costs, since they were not controlled by the production subdivisions of oil company. Structure of immediate direct costs of oil land consisted of the following: labor costs for farm bosses, bull gangs; roustabouts, operators, boreholes cleaning from sand, etc.

\section{Result}

Generally we can distinguish four stages of costs formation: acquisition and lease of property (lands), oil prospecting, development and exploitation of oil lands and oil producing. That is why companies bore significant spending on acquisition and lease of oil lands and geologic exploration. Costs for acquisition (lease) of oil lands were capitalized. Depreciation reserves were established; herewith depreciation was recorded not as production costs but as other costs (separate item of costs in the profit and loss report). Upon expiration of undeveloped lands lease (possession) term provided that the lease term is not prolonged, then both the depreciation reserve and capitalized costs (capital assets) were reduced to the total value of the undeveloped lands.

Costs for geological exploration works in 30-40s of the XX century were defined as costs for determination and preliminary volume and depth of oil occurrence except for drilling activities. In case the works performed were inefficient (oil was not explored), then the occurred costs were deducted as expenditures (losses), in case of oil detection they were capitalized. Costs for oil land acquisition and geological exploration works were distributed between the oil lands pro rata with their areas.

However according to the researches of Haynes, L. [11] oil companies in 40 s used contradictory approaches to costs and results calculation: costs for lands acquisition (capitalized by $90 \%$ of companies); lease of lands (capitalized by $12 \%$ of companies); costs for exploitation works (capitalized by slightly more than $1 \%$ of companies); costs for levies and charges related to property acquisition (capitalized by more than $50 \%$ of companies); partial payment to the vendor of the oil land (according to the oil land acquisition contract) by the amount of income from oil realization (capitalized immediately by $40 \%$ of companies, capitalized in proportion to out-payments approximately by $8 \%$ of companies, were not fixed at all - by more than $50 \%$ of companies).

There is an interesting fact that about only $50 \%$ of companies capitalizing costs and then applying methods of depreciation, i.e included capitalized costs by parts to the operating costs structure during the term of objects operation. Other companies recorded capitalized amounts in account books, and then deducted the whole cost: either at the moment of oil land commissioning, either upon depletion of oil reserves, or at the moment of making decision on refusal of further land exploitation. By the end of 50s of the XX century Smith, C. and Brock, H. [9] specified that the three variants of costs distribution to research and exploration works had already been used: writing-off expenditures (period expenses), capitalization in case of positive result and capitalization regardless of positive result were used in enterprises. The third variant was used on rare occasions. Such tendency of costs recording was in use in $60 \mathrm{~s}$ of the past century as well. As a result, the application of three methods of financial result determination gained widespread: without capitalization of costs for research works, with capitalization in case of positive result of research works and with complete capitalization of costs for research works. It was recognized that the third method of costs accounting for oil and 
gas exploitation, when the costs were capitalized regardless of the boreholes productivity, was of most interest for managers, since it was more informative from the point of view of information presentation on oil company activity results. It is impossible to explore new oil fields without effective geological research works. That is why these costs were considered as depreciation amounts in the process of financial results definition for all afteryears of oil producing on the land till the moment of its operation term expiration.

In 1970s of the XX century the methods of costs calculation in oil producing companies caused hot discussions in professional environment. The second method was named "successful efforts method" (method of costs accounting based on oil and gas exploitation, when only the cost of successfully operating oil boreholes are considered as capital, whereas the cost of non-productive boreholes or lands is specified as expenditure) or SEA method (successful efforts accounting). Gradually method selection was reduced to two methods: SEA and FCA. Thus the methods of costs calculation became the tool of predictive assessment of the company value, i.e. the method of strategic management accounting and controlling.

Costs detalization was performed in relation to certain groups thereof. For example in 50-60s a number of companies in the USA used the following materials grouping [Irving, R., 8]: class A - $100 \%$ of the market value (i.e new materials), class B - $75 \%$ (used materials, complying with all specified requirements and suitable for reuse), class C -50 $\%$ (remanufactured and repaired materials), class D - $25 \%$ (materials which can be used for other purposes) and class $\mathrm{E}$ - residue value (scrap value). Materials were often returned from lands to the warehouses, repaired and used again in production or for other purposes. As an example of such material may serve the casing pipes or casing columns for boreholes lining, materials for pipeline laying, for pumping production, etc. They were often transferred from one group to another, for example, after remanufacturing - from group $\mathrm{C}$ to group $\mathrm{B}$ and there appeared the valuation variance. Costs were reported in materials reports.

Data on depreciation costs was important for decisions making. In 1930-40s depreciation costs amount calculation depending on the volume of produced oil was considered as advanced depreciation method (the most widely used variant for that period was straight line method and method of decreasing rates: rate $40 \%$ - the first year; rate $30 \%$ - in the second year; rate $20 \%$ - in the third year; rate $10 \%$ in the fourth year). However strong interrelation of the received amount of depreciation allowances with financial results were important for cost controlling. The standard formula for depreciation costs value calculation may be presented as follows:
$D=\frac{I-S}{\sum Q} \times Q$
where
$\mathrm{D}$ - value of depreciation costs for the period, $\mathrm{MU}$;
I - initial cost of equipment, MU.;
$\mathrm{S}$ - disposal value - $10 \%$ of the initial cost, MU
$\mathrm{Q}$ - volume of oil producing per month, in barrels;
$\sum \mathrm{Q}$ - total calculated volume of recovering from boreholes, in barrels.

For the purposes of company management, forecast value of cost, required for complete exploitation of oil lands, might be added to the numerator:

$$
D=\frac{I-S+E}{\sum Q} \times Q(2)
$$

where

$\mathrm{E}$ - pre-estimated cost value, required for complete exploitation of oil land, in MU.

While using this method named "Californian system", the amount of depreciation and consequently the value of financial results in management and tax accounting were different. In 50 s the following formula for calculation of depreciation amount by Californian method gained widespread in the USA [Irving R., 8]

$$
D=\frac{I-S+E}{\sum Q+\sum P} \times Q
$$

where

$\sum \mathrm{P}$ - forecast value of oil producing in lands, in barrels

By the end of 50s of XX century, as was noted by Smith, C. and Brock, H [9], discussions on necessity of depreciation of undeveloped oil lands became topical. Followers of accrual of depreciation for undeveloped oil lands put forward the following argument in favor of this approach: according to the experts research from 75 to $90 \%$ of the undeveloped land area will not be further used, that results in correlation of costs and results - only the insignificant part of costs for acquisition of undeveloped oil lands thereafter will generate profit. Opponents of this approach produced their arguments: depreciation of undeveloped lands is not prescribed by the tax legislation; there is no reasons for considering that the term of beneficial use or land cost are reducing, if the owner has the same rights to the land for the last year of exploitation as in the first year. 


\section{Conclusion}

Costs and results, being the key objects of management accounting and controlling, form the basis for establishment of controlling model and management accounting model. It is important to define separately controlled corporate costs of oil producing company and controlling units, costs by objects: shops and boreholes, teams, cost objects, activity types, stages of boreholes life cycle. This approach allows to improve the oil production company management system.

\section{References}

Zhou, Q., Wang, L.-Y. Simulation analysis of the oil gathering and transportation process on activity-based costing // Advanced Materials Research, 2011. pp 395-400.

Holmes, P.D. A model for the costing of oil spill clearance operations at sea // International Oil Spill Conference, IOSC 2005, 2005. pp 4818.

Bryant, L. Relative value relevance of the successful efforts and full cost accounting methods in the oil and gas industry // Review of Accounting Studies, 2003. pp. 5-28.

Tatikonda, Lakshmi U.,Tatikonda, Rao J. Cost accounting regulations in oil and gas industries // Gateway Energy Conference, 1978. pp 311-314.

Collins, D.W., Dent, W.T. The proposed elimination of full cost accounting in the extractive petroleum industry. An empirical assessment of the market consequences // Journal of Accounting and Economics, 1979. pp 3-44.

Bouachera, T., Kishk, M.,Power, L. Towards a generic framework for whole life costing in the oil industry // Association of Researchers in Construction Management, ARCOM 2007 - Proceedings of the 23rd Annual Conference, 2007. pp 863-871.

Paine, P.M. Oil production methods (with a chapter on accounting systems). - San Francisco: Western engineering publishing $\mathrm{Co}_{\text {., }}$ 1913. - 209-239 C.

Irving, R.H. Accounting practices in the petroleum industry / R.H. Irving, V.R. Draper. - New York: The Ronald Press Company, 1958. $247 \mathrm{p}$.

Smith, C.A. Brock, H.R. Accounting for oil and gas producers: principles, procedures and controls. - Prentice-Hall, Inc, 1959. - 536 p.

Kulikova, L.I., Goshunova, A.V. Efficiency measurement of professional football clubs: A non-parametric approach // Life Science Journal 11 (SPEC. ISSUE 11), 2014. pp. 117-122.

Haynes, L.C. Accounting for leasehold costs in the petroleum industry / L.C. Haynes // Journal of Accountancy. - 1942. - № 4. - P. 327 $-340$.

Finnell, J.C. Full Costing in the oil and gas producing industry // Management Accounting, 1967. pp. 47-53. 